University of Nebraska - Lincoln

DigitalCommons@University of Nebraska - Lincoln

Educational Psychology Papers and

Publications

Educational Psychology, Department of

January 2001

\title{
Teaching Child Development Via the Internet: Opportunities and Pitfalls
}

Theresa A. Graham

University of Nebraska-Lincoln

Follow this and additional works at: https://digitalcommons.unl.edu/edpsychpapers

Part of the Educational Psychology Commons

Graham, Theresa A., "Teaching Child Development Via the Internet: Opportunities and Pitfalls" (2001). Educational Psychology Papers and Publications. 66.

https://digitalcommons.unl.edu/edpsychpapers/66

This Article is brought to you for free and open access by the Educational Psychology, Department of at DigitalCommons@University of Nebraska - Lincoln. It has been accepted for inclusion in Educational Psychology Papers and Publications by an authorized administrator of DigitalCommons@University of Nebraska - Lincoln. 


\title{
COMPUTERS IN TEACHING
}

\section{Teaching Child Development Via the Internet: Opportunities and Pitfalls}

\author{
Theresa A. Graham \\ Department of Educational Psychology \\ University of Nebraska-Lincoln
}

National trends suggest that the demand for distance education will continue to rise. In this article, I describe the development, implementation, and evaluation of a cross-listed undergraduate and graduate-level child development course on the Internet. In addition, I discuss the content and pedagogical goals for the class in the context of technological constraints. Finally, I address the future directions of distance education.

In the context of declining college enrollments and increasingly diverse student bodies, college and university communities have sought strategies to meet the changing needs of students (Hansen \& Gladfelter, 1996; Spear \& Mocker, 1990; Stadtlander, 1998). Distance education has been one of the primary responses to delivering part, or all, of academic curricula (Moore \& Thompson, 1990). Distance education is a broad term for a number of educational technologies including teleconferencing, television courses, e-mail, correspondence education, CD-ROM, and bulletin boards or news groups. These technologies differ in their delivery (e.g., text based, video based, real time, virtual time, synchronous dialogue, and asynchronous dialogue) and create vastly different contexts for learning. However, comparative studies of traditional versus nontraditional classrooms indicate that these different educational contexts do not hinder student learning (e.g., Cheng, Lehman, \& Armstrong, 1991; Grimes, Nielson, \& Niss, 1988; Souder, 1993). In fact, these alternative contexts afford unique educational opportunities (Gillette, 1996). For example, foreign language courses can link students directly to native speakers in other countries. Moreover, students and faculty report high satisfaction with distance learning courses (e.g., Powers \& Mitchell, 1997; Santoro, 1997).

National trends suggest that the demand for distance education will continue to rise (Dillman, Christenson, Salant, \& Warner, 1995). In 1995, 15\% of Americans surveyed had experienced distance education, and nearly $75 \%$ of the adults believed that more courses should be developed using distance methods. In light of this demand, many college and university faculty face the challenge of learning a new teaching technology. In this article, I describe the development and implementation of a cross-listed undergraduate and graduate-level child psychology course delivered on the Internet. I outline both the opportunities and the potential pitfalls of teaching in a virtual classroom and demonstrate

that pedagogical goals need not be sacrificed in the interest of technological advances.

\section{The Course}

During the summer of 1999, I taught a 5-week child development course via the Internet using Blackboard CourseInfo (http://www.blackboard.com). Blackboard CourseInfo is a Web page course management system, providing instructors with an instructional template. The template is organized into eight folders: announcements, course information, staff information, assignments, communication, external links, and student tools. In announcements, instructors can post information that students can see immediately when they access the page. In course information, staff information, and assignments, an instructor can post specific course information such as a syllabus, lecture notes, and assignments. In the communication folder, students can access an e-mail system, discussion boards, a student roster, a virtual chat room, and student and group Web pages. In external links, an instructor can list other Web pages that are relevant to the course. Finally, in student tools, students can edit a Web page of their own, check their grade, and get access to a manual describing how to use Blackboard CourseInfo. Given the flexibility of Blackboard CourseInfo, an instructor can tailor a course to fit the particular needs of the course and the students. An instructor can use as much or as little as he or she wants. Although I did not use all of the tools on the Web page (e.g., group and student Web pages) for my course, I used many of the tools.

Seventeen students registered, and 14 completed the course. In the summer, the student body generally consisted of undergraduate and graduate students from various departments (the class is cross listed as an upper-level undergraduate course and a master's course) and elementary school teachers. In previous versions of the course, students attended class 5 days per week in a traditional classroom. In an effort to reach students who might have a conflict with attending a traditional 5-day-a-week summer class, I decided to offer the entire class in an alternative format using the Internet. I chose the Internet over other distance educational technologies (e.g., teleconferencing) to accommodate students' schedules. Internet instruction provides greater flexi- 
bility than teleconferencing because it takes place in "virtual time," allowing students to access course material according to their personal scheduling needs.

When I began, I had little knowledge of distance education or of the various Internet-based technologies. To increase my awareness of the technology and of the pedagogical theories behind distance education, I participated in a workshop offered by our Teaching and Learning Center. This workshop highlighted the importance of using pedagogical goals to shape the curriculum rather than letting distance technology drive the curriculum. This recommendation led me to outline the goals of my class first and then to find technology that would allow me to meet those goals.

Although my primary goal was to deliver a course in which students could access the materials and participate in the class according to their personal scheduling needs, I also had content goals specific to a master's-level course on child development and pedagogical goals to promote effective instruction. One content goal was to provide an overview of child development, including basic terminology, basic research findings, and some current topics. In addition, I wanted students to be able to interpret and analyze research findings. In summary, I established four main goals for the students: small group discussion, large group discussion, one-on-one interaction with the professor, and exploration of individual interests.

\section{Content Goals}

\section{Course Content}

I used lecture notes, course pack readings, and a textbook to present basic content information. I posted the lecture notes, syllabus, and a course timeline separately on my Blackboard CourseInfo Web site that I created for the class. Although I allowed students to proceed through the class at their own pace, I provided a suggested time line, indicating when assignments were due and what they should be reading each day in the textbook, course pack, and lecture notes. To facilitate time management, I created folders for each week, and, within those folders, separate folders for each "day." In these folders, I included the lecture notes, discussion questions and activities tied to the lecture notes, appropriate Web links, and video clips when applicable. For example, in a traditional class session, I might use specific lecture material, activities, and videos. On the Internet, I included all of these in a package.

The information contained in the lecture notes was similar to the information that I provide in a traditional lecture. Although the lecture notes were primarily in a text format, Blackboard CourseInfo provides a template to add Web links within the text. Thus, for a number of lectures, I was able to link students to other sites that were relevant to particular content. For example, if I was discussing the stages of prenatal development, I could link students to a Web site with ultrasound pictures of prenatal development.

I was also able to augment the text-based lecture notes by loading relevant video clips onto the Web page. In a traditional classroom, I show these videos, and students get to view them once. On the Internet, students were able to watch the videos numerous times, potentially helping them to solidify their understanding.

Finally, I inserted "thinking time" questions into the text of the lecture notes. In a traditional lecture-based class, I often stop lecturing and ask students questions about the material. In the Internet format, I did not want students to read the lecture notes without stopping and thinking about the applicability of a particular topic. I used the thinking time questions to encourage this critical thinking process. Thus, although much of the information was text based, I used a number of strategies to help students integrate the material.

\section{Evaluating Research}

An important component of my course is helping students learn to evaluate empirical research and theory. In the course, I provided implicit and explicit opportunities for students to evaluate research. For most of these assignments, I used e-mail communication. First, students e-mailed me two reactions based on the course-pack readings each week. These reactions allowed me to determine whether students were interpreting the research correctly. I provided individual feedback using Blackboard CourseInfo's e-mail program.

Students also completed two compare-and-contrast papers in which they evaluated two empirical articles on the basis of theoretical and empirical similarities and differences. Students were able to use the e-mail function in Blackboard CourseInfo to submit their papers.

In a third assignment, I matched students with a developmental psychologist currently working either in an academic or applied setting. (Prior to the class, I had contacted developmental psychologists and solicited their participation in this assignment.) I provided students with the psychologist's e-mail address and a copy of an empirical article that the psychologist had published. For the assignment, students read the article and e-mailed the psychologist at least twice. In the e-mail interactions, the students asked the psychologists about their professional careers and about the articles that the students read. One of the purposes of this assignment was to demonstrate for students that the field of developmental psychology is closer to them than their textbook or course pack. If they have a question about research that they read, they can turn to many resources, including the author. E-mail technology may reduce the perceived barriers to accessing information. E-mailing a developmental psychologist about their work may be less threatening than meeting in person, writing a letter, or calling on the phone.

\section{Pedagogical Goals}

\section{Small Group Discussion}

In the traditional classroom, I routinely use small group discussions. The learning that occurs in small peer groups greatly contributes to students' construction of their knowledge (Vygotsky, 1962). A potential drawback of a virtual classroom is the lack of peer interaction. To remedy this 
problem, I matched small groups of students (2 to 3 students). Students met online with their small group each week for approximately 60 to $90 \mathrm{~min}$ to discuss course material. Blackboard CourseInfo includes a virtual chat room in which students were able to meet online for synchronous dialogue.

During the group times, I instructed students to discuss the questions that I posed at the end of each day of lecture notes. In many of the lectures, I used the thinking time questions as discussion questions for the small group. With this arrangement, I intended for students to think about these issues on their own and then to discuss the issues with their peers. Because the groups were meeting online, I was able to drop in on some of their small group discussions and facilitate the discussion.

\section{Large Group Discussion}

Whole class discussions are also important for learning. In my traditional course, I often reconvene the class after a small group discussion to share what the smaller groups discussed. To recreate the same phenomenon online, I used the feature (i.e., the discussion board) that allows a group to post a summary of their discussion. Students could review what other groups discussed and offer their reactions. In addition, I was able to review what small groups were discussing and could comment either to the whole class or direct comments to specific groups or individuals.

I also asked students to share information with the whole class by posting child development Web sites. Each week, students e-mailed me a Web site related to child development. Because these Web links were located on the class Web page, students could visit the sites without having to type in the Internet address. In addition, we talked about the reliability of Internet sources and how students can evaluate the information that they find on the Internet. I encouraged students to look at each other's Web sites. In addition, I instituted "best of the Web" awards. Students examined all the Web sites and voted on the best Web site. Students with the best Web site received nominal prizes (e.g., stickers).

\section{One-on-One Interaction}

For most of the one-on-one interaction, I relied on the e-mail system. Students were able to e-mail me whenever they wanted. There were times that I would be in e-mail contact with a student multiple times within a day. Also, because Blackboard CourseInfo offers a virtual chat room, I could arrange to meet a student online to chat individually. In a sense, I could hold "office hours" without seeing the student.

The weekly reactions and Web critiques also provided one-on-one interaction between the students and myself. Students e-mailed both of those responses to me, and I provided individual feedback for them through e-mail. In the case of the weekly reactions, students often raised general issues of particular interest to them. In these situations, I was able either to provide feedback or to refer them to a relevant article or person who would be able to address their question if they wanted more information.

\section{Exploring Individual Interests}

The Internet format did not hinder students' ability to explore their specific interests. The Web critiques provided ample avenue for students to explore areas of interest. For example, if they had a question about Attention Deficit Hyperactivity Disorder (ADHD), I might suggest that they find a Web site related to ADHD. In addition, I required students to select the topic for their compare-and-contrast papers. Finally, in the weekly reactions, students often connected the course material to individual interests.

\section{Student Performance}

I based students' grades on their summaries of Web sites, their weekly reactions to the readings, the summary of their interaction with a developmental psychologist, their two papers, a take-home final, and their class participation. I measured class participation by students' discussion board postings. It is difficult to compare students' performance in the Internet course with students' performance in a traditional class because the requirements were not the same. In general, I was very impressed with students' diligence and performance in the Internet course. It was clear by their weekly reactions and their summaries of the discussion board postings that students were working hard. Students found interesting Web sites and provided helpful summaries of the information found there.

In addition, I was impressed with the level of knowledge that students displayed in their weekly reactions and in their discussion board postings. There were some discussion board questions that I thought would be especially challenging for students. I was almost surprised at the responses that I received. Although I do not have specific empirical evidence, the students in the Internet course seemed to grasp ideas more quickly than in a traditional course. There are many possible explanations of this impression. Perhaps the students in my Internet course were more knowledgeable than previous groups of students. However, from the information that I have regarding students' backgrounds, the Internet group did not seem significantly different from other classes. It could be that because students spent more time discussing the material, they were able to develop more complex answers. It could also be that because I required students to read the course lecture notes before meeting in a group, students had time to think about the issues before the meeting. Although I do not have direct data to support or refute any of these hypotheses, it does seem that more systematic exploration of the benefits of Internet instruction is warranted.

Academic honesty was no more difficult to enforce in an Internet course than in a traditional course. Because most of the assignments were text based and individualized, I could easily check for individual work. For example, if one student submitted a Web site in the first week, then other students had to find other sites to submit. Also, students wrote their papers on different topics and used different resources. Finally, students submitted their assignments from their own e-mail accounts. Although there are always ways for students 
to jeopardize academic integrity, the Internet course was no more vulnerable than traditional courses. In fact, the nature of the Internet assignments and the regular individual contact between the students and myself made it easier to ensure academic honesty.

\section{Student Evaluations}

At the end of the semester, students completed an evaluation of the course. I compared these evaluations to evaluations of the same course offered in a traditional format in the summer of 1996. I found no significant differences in students' satisfaction with the course or the professor between the traditional course and the Internet course. In general, students were satisfied with the Internet course and believed that the course helped them to develop critical thinking. All students reported that the course helped them to become more effective for their future career. Moreover, they reported that they would be very likely to recommend the class and the instructor to other students.

The evaluation also asked students to respond to questions about the time they spent on the class, the amount of time they spent in class discussion, and the amount of contact they had with me. Students perceived that they spent a little more time on the Internet course than in a traditional course. Students made comments such as "good, but a lot of work." However, they also perceived that in comparison to a traditional class, they spent more time talking to their classmates about class content in the Internet class and had about the same amount of contact with me even though the students met with me only once. Thus, one-on-one interaction, small group discussions, and large group discussions do not have to be sacrificed in a virtual classroom.

\section{Pitfalls}

Although the students' evaluations were positive, there were some pitfalls. First, a number of students noted that they missed the face-to-face interaction. One student noted that although there were opportunities to interact online, she missed the social nature of the traditional class. Internet instruction may not be for everyone. In future classes, I will try to increase the student-to-student and student-to-instructor interaction by encouraging more synchronous dialogue with myself and between other students. For example, I could offer regular online office hours so that students would know that I would be available for discussion at certain times. In addition, I could mix the small groups in the middle of the semester so that students have opportunities to get to know other students in the course.

Another concern raised by a few students was that they did not receive immediate feedback. This was a surprising comment given that I checked and responded to my e-mail messages at least once a day. Students also mentioned this issue when they were working on the "meet the psychologist" assignment. I received a few e-mails from students when the psychologist had not responded to them within a day or two. Stadtlander (1998) noted a similar finding and suggested that students in an online course may expect that the instructor should be accessible $24 \mathrm{hr}$ per day just like the course material. Therefore one may need to address this expectation at the start of the course.

Another pitfall of an online course is the amount of time required of the students and the instructor. Although students estimated that they spent only a little more time in this course in comparison to traditional courses, some students commented that it was difficult to limit the time that they spent on the class. One student stated, "Once I got onto the Internet, it was hard to get off. I felt as though I could work for days on it." Unlike a traditional course that has a start and end time, a virtual course has no imposed time limits inside the classroom. As an instructor, I, too, found it difficult to impose limits on the amount of time that I would spend responding to student inquiries. No matter when I checked the Web site or my e-mail, there was always something new.

The final pitfall of the course was computer limitations. Although all of the students rated Blackboard CourseInfo as easy to use, a few students experienced computer difficulty. For the most part, the difficulties centered on the capabilities of their personal computer. If they had a slow modem connection or computer processor, they had a more difficult time participating in the virtual chat rooms. In addition, some students reported initial difficulties in accessing the video clips that I had streamed onto the Web page. For the most part, the computer difficulties were reconciled. However, as educators look to the future of distance education, it is critical that we consider the computer capability and accessibility of our audience. Three students dropped out of the class in the first week because of computer difficulties.

\section{Conclusions}

Although there were many differences in teaching in a virtual classroom compared to teaching in a traditional classroom, I did not have to sacrifice content and pedagogical goals in the name of convenience or technology. Indeed, the online format provided opportunities that are not typically available in a traditional classroom. For example, the centralized Web page provided a haven for child development and classroom dialogue. Students could sign on at any time and find out what other students were thinking. Students could easily send e-mails to individuals, groups of students, or the whole class. It permitted more individuality and ultimately more shared knowledge about child development issues.

In addition, the online format gave more opportunity for other activities. In a traditional course, if an instructor does not cover a topic, then students will not learn it. Because students had all of the basic information in the textbook, course pack, and, more important, the lecture notes, there was more time to discuss and think about the information and participate in activities to integrate the knowledge.

With any educational tool there are things to be gained and things to be sacrificed. As one student stated, "it was much more work, but well worth it." Although distance education will reduce some barriers to new training and education in the 21 st century by creating a virtual classroom, some barriers will remain. In the current environment, distance learning may not be appropriate for all students or all disci- 
plines. It is imperative that as educators we remain sensitive to the future challenges of distance education.

\section{References}

Cheng, H. C., Lehman, J., \& Armstrong, P. (1991). Comparison of performance and attitude in traditional and computer conferencing classes. The American Journal of Distance Education, 5, 51-64.

Dillman, D. A., Christenson, J. A., Salant, P., \& Warner, P. D. (1995). What the public wants from higher education: Workforce implications from a 1995 national survey (Tech Rep. No. 95-52). Pullman: Washington State University, Social and Economic Sciences Research Center.

-Gillette, D. H. (1996). Using electronic tools to promote active learning. New Directions for Teaching and Learning, 67, 59-70.

Grimes, P., Nielson, J. E., \& Niss, J. F. (1988). The performance of nonresident students in the "Economics USA" telecourse. The American Journal of Distance Education, 2, 36.

-Hansen, N. E., \& Gladfelter, J. (1996). Teaching graduate psychology seminars using electronic mail: Creative distance education. Teaching of Psychology, 23, 252-256.

Moore, M. G., \& Thompson, M. M. (1990). The effects of distance learning: A summary of literature (Research Monograph No. 2). Athens: Southeastern Ohio Telecommunications Consortium. (ERIC Document Reproduction Service No. ED 330 321)
Powers. S. M., \& Mitchell, J. (1997, March). Student perceptions and performance in a virtual classroom environment. Paper presented at the annual meeting of the American Educational Research Association, Chicago.

Santoro, G. M. (1997, April). Design principles for online learning environments. Paper presented at the meeting of the Pennsylvania Academy for Computer and Information Science Education, Clarion, PA.

Souder, W. E. (1993). The effectiveness of traditional versus satellite delivery in three management of technology master's degree programs. The American Journal of Distance Education, 7, 37-53.

Spear, G. E., \& Mocker, D. W. (1990). The future of adult education. In S. B. Merriam \& B. M. Cunningham (Eds.), Handbook of adult and continuing education (pp. 640-649). San Francisco: Jossey-Bass.

Stadtlander, L. M. (1998). Virtual instruction: Teaching an online graduate seminar. Teaching of Psychology, 25, 146-148.

Vygotsky, L. S. (1962). Thought and language. Cambridge, MA: MIT Press.

\section{Note}

Send correspondence to Theresa A. Graham, University of Nebraska-Lincoln, Department of Educational Psychology, 219 Bancroft Hall, Lincoln, NE 68588-0345; e-mail: tgraham1@ unl.edu. 